\title{
GMR
}

\section{Mini tomato genotypes resistant to the silverleaf whitefly and to two-spotted spider mites}

\author{
G.M. Maciel, R.S. Almeida, J.P.R. da Rocha, V. Andaló, G.R. Marquez, \\ N.C. Santos and R.R. Finzi \\ Instituto de Ciências Agrárias, Universidade Federal de Uberlândia, \\ Campus Monte Carmelo, Uberlândia, MG, Brasil \\ Corresponding author: G.R. Marquez \\ E-mail: grepeza@gmail.com
}

Genet. Mol. Res. 16 (1): gmr16019539

Received November 16, 2016

Accepted February 17, 2017

Published March 22, 2017

DOI http://dx.doi.org/10.4238/gmr16019539

Copyright (C) 2017 The Authors. This is an open-access article distributed under the terms of the Creative Commons Attribution ShareAlike (CC BY-SA) 4.0 License.

\begin{abstract}
The mini tomato production has expanded, becoming an amazing alternative for enterprise. Despite all commercial potential, the cultivation has the occurrence of pests as main obstacle during the crop development. Nowadays, there are no researches that aimed obtaining genotypes with high acylsugar content, capable of providing a broad-spectrum resistance to pests. This study aimed the selection of mini tomato genotypes, with high acylsugar content, and checking the resistance level to the silverleaf whitefly [Bemisia tabaci (Gennadius)] and to the two-spotted spider mites (Tetranychus urticae Koch). Sixteen genotypes were evaluated, from which 12 were on the generation $\mathrm{F}_{2} \mathrm{BC}_{1}$, originated from the interespecific cross between Solanum pennellii versus Solanum lycopersicum L. and 4 were check treatments, being three of cultivated tomatos (cv. Santa Clara, UFU-02, and UFU-73) and the wild accession LA-716 (S. pennellii). The variables analyzed were acylsugar content, repellency to the silverleaf whitefly, repellence to the two-spotted spider mites, and density of glandular trichomes. The genotypes UFU$22-\mathrm{F}_{2} \mathrm{BC}_{1} \# 9$ and UFU-73- $\mathrm{F}_{2} \mathrm{BC}_{1} \# 11$ have high acylsugar content and both are resistant to the pests that were evaluated. New studies must be
\end{abstract}

Genetics and Molecular Research 16 (1): gmr16019539 
conducted seeking for inbred lines, obtained from the selected genotypes, aiming to get commercial hybrids with high acylsugar content.

Key words: Allelochemical; Arthropod pests; Biotic stress; Tomato

\section{INTRODUCTION}

The tomato [Solanum lycopersicum (L.)] is one of the vegetable crops with most economic importance all over the world, being classified in different groups: Santa Cruz, caqui, round, saladette, and mini tomato (Alvarenga et al., 2013). Among these, the last one has been highlighted on the Brazilian market. In 2012, the mini tomato seed's market, in Brazil, reached US\$ 943190, and the seeds were cultivated in more than 300 hectares in greenhouses (ABCSEM - Associação Brasileira de Comércio de Sementes e Mudas, 2014). Nowadays, there are many hybrids of mini tomatoes, with commercial potential, that have small fruit size and sweeter flavor in comparison to the other groups (Maciel et al., 2016).

During the tomato cropping, many species of arthropod pests affect the yield (Maciel et al., 2011; Oliveira et al., 2012; Czepak et al., 2013; Neiva et al., 2013; Maciel and Silva, 2014). The chemical control (insecticides and miticides) has been the most used method since the XX century (Sato et al., 2009; Silveira et al., 2011). Facing that, it is necessary to obtain new strategies aiming to reduce the exclusive use of chemical control. In breeding programs, specific methods have been successfully used (interespecific cross and backcross) in order to reduce the attack of the most common pests in the tomato crop (Maciel et al., 2009; Gonçalves Neto et al., 2010; Maluf et al., 2010; Oliveira et al., 2012; Neiva et al., 2013). The use of the wild accession, Solanum pennellii, allows obtaining lines (Maciel et al., 2009; Gonçalves Neto et al., 2010) and hybrids of tomato, with broad-spectrum resistance to pests (Maluf et al., 2010; Maciel et al., 2011; Oliveira et al., 2012; Neiva et al., 2013). The wild species, S. pennellii, has a secondary metabolite that acts as an allomone to arthropods, named acylsugar, which when combined with the presence of glandular trichomes, become the mainly responsible for induce pest's resistance on tomato plants. The presence of acylsugar is due to an action of a recessive allele, with incomplete dominance towards low levels (Gonçalves et al., 2007).

Among the main pests that occur on tomato lands, the two-spotted spider mites, Tetranychus urticae Koch (Acari: Tetranychidae), and the silverleaf whitefly, Bemisia tabaci (Gennadius) (Hemiptera: Aleyrodidae), have been highlighted. The two-spotted spider mites have been responsible for damages on tomato plants in Brazil since 70's, and it is an extremely polyphagous and cosmopolitan pest (Sato et al., 2009; Silveira et al., 2011). Sato (2015) detected productivity losses exceeding $30 \%$, caused by the spider mites. The silverleaf whitefly, one of the major tomato pests, can cause damages above $60 \%$ in the production (Dinsdale et al., 2010). It is an important pest all over the world, being responsible for the transmission of a begomovirus disease complex in the tomato crop (Dinsdale et al., 2010; Esashika et al., 2016).

Despite all commercial potential and the expansion of tomato lands, nowadays, there are no mini tomato hybrids with high acylsugar content. Facing that, this study aimed obtaining mini tomato genotypes rich in acylsugar, and checking their resistance to B. tabaci and T. urticae.

\section{MATERIAL AND METHODS}

The experiments were conducted at the Experimental Horticulture Station

Genetics and Molecular Research 16 (1): gmr16019539 
$\left(18^{\circ} 42^{\prime} 43,19^{\prime \prime} \mathrm{S}\right.$ and $47^{\circ} 29^{\prime} 55,8^{\prime \prime}, 873 \mathrm{~m}$ above sea level) and at the Genetic Resources Laboratory of the Federal University of Uberlândia - UFU, Monte Carmelo Campus, in the period of April 2013, to November 2016.

Twelve genotypes, in $\mathrm{F}_{2} \mathrm{BC}_{1}$ generation, were evaluated (UFU-22- $\mathrm{F}_{2} \mathrm{BC}_{1} \# 1$, UFU-22$\mathrm{F}_{2} \mathrm{BC}_{1} \# 2$, UFU-22- $\mathrm{F}_{2} \mathrm{BC}_{1} \# 3$, UFU-22- $\mathrm{F}_{2} \mathrm{BC}_{1} \# 4$, UFU-22- $\mathrm{F}_{2} \mathrm{BC} \mathrm{C}_{1} \# 5$, UFU-22- $\mathrm{F}_{2} \mathrm{BC}$, $\# 6$, UFU$22-\mathrm{F}_{2} \mathrm{BC}_{1} \# 7, \mathrm{UFU}-22-\mathrm{F}_{2} \mathrm{BC}_{1} \# 8$, UFU-22- $\mathrm{F}_{2} \mathrm{BC}_{1} \# 9$, UFU-22- $\mathrm{F}_{2} \mathrm{BC}_{1} \# 10$, UFU-73- $\mathrm{F}_{2} \mathrm{BC}_{1} \# 11$, and UFU-73- $\left.\mathrm{F}_{2} \mathrm{BC}_{1} \# 12\right)$. They were obtained from an interespecific cross between the wild accession LA-716 (S. pennellii) versus pre-commercial lines of mini tomato (UFU-73 and UFU-2) (S. lycopersicum). The lines, UFU-73 and UFU-2, were used as check treatments and as recurrent parents in the backcross process. The first one has a determine growth habit (recessive homozygous, sp/sp), $10^{\circ}$ Brix, yellow fruits, weighing $18 \mathrm{~g}$ on average, and is susceptible to pests. The second line has an indeterminate growth habit (dominant homozygous, $\mathrm{SP} / \mathrm{SP}), 11^{\circ}$ Brix, fruits with red colors, weighing $15 \mathrm{~g}$ on average, and is also susceptible to the pests. The other two check treatments used were the wild accession LA-716 (S. pennellii, parent donor), for being rich in acylsugar and to be an allelochemical able to provide a broad-spectrum resistance to pests on tomato plants, and the commercial cultivar Santa Clara (susceptible to pests), totalizing sixteen genotypes evaluated in the experiment.

The genotypes were sown in May 2016 using a polystyrene seed tray containing 200 cells, and filled with commercial coconut fiber substrate. Thirty-five days after sowing, the plants were transplanted into pots (5-L volume), containing the same substrate that were used for seedling's production. The tomato plants were cultivated in a bow-type greenhouse, measuring $7 \times 21 \mathrm{~m}$ with the ceiling $4 \mathrm{~m}$ high, covered with a transparent polyethylene film of $150 \mu$, additivated against ultraviolet rays and curtain side of white and anti-aphid scream. The experiment was set up in a randomized complete block design, with four replications (blocks), totalizing 64 plots (16 genotypes x 4 blocks). Each plot consisted of five plants, culminating in 320 plants. The same plants were used in all evaluations, in order to quantify the acylsugar content, the trichome density, and the repellency to the two-spotted spider mites and to the silverleaf whitefly. The average temperature and the relative humidity, during the start of the evaluations by the end of it, were, respectively, $18.7^{\circ}$ to $34^{\circ} \mathrm{C}$ and 72 to $95 \%$.

Leaflets were collected from the upper third of the plants 75 days after sowing, in order to quantify the acylsugar content. Seeking the allelochemical extraction, a sample composed by six leaf discs (equivalent to $4.2 \mathrm{~cm}^{2}$ ), was collected in all five plants from each plot. After conditioned in test tubes, the samples were assessed for acylsugar content, according to the methodology proposed by Resende et al. (2002) and adapted by Maciel and Silva (2014).

The silverleaf whitefly used in the tests were obtained from naturally infested tomato plants, in Monte Carmelo City, in January 2016, and thereafter, the insects were reared onto susceptible tomato plants, cv. Santa Clara, in a greenhouse, measuring $6 \times 4 \mathrm{~m}$ with the ceiling $2 \mathrm{~m}$ high, covered with transparent polyethylene film of $150 \mu$, additivated against ultraviolet rays and curtain side of white and anti-aphid scream.

The test of resistance to the silverleaf whitefly was done using the methodology developed by Maluf et al. (2010). The number of eggs and nymphs per $\mathrm{cm}^{2}$ of leaf area was counted with an aid of a microscope stereoscope (40X), 90 days after sowing. In each genotype, five leaflets, from the upper third of the plants, were evaluated. In order to assess the number of adults, a mirror was used, aiming to visualize the insects before they could leave the leaves.

The two-spotted spider mites, used in the tests, were also obtained from naturally infested tomato plants, in Monte Carmelo City, in January 2016, and thereafter, the insects

Genetics and Molecular Research 16 (1): gmr16019539 
were reared onto susceptible tomato plants, cv. Santa Clara, in a greenhouse, measuring $6 \times 4$ $\mathrm{m}$ with the ceiling $2 \mathrm{~m}$ high, covered with transparent polyethylene film of $150 \mu$,additivated against ultraviolet rays and curtain side of white and anti-aphid scream.

The repellence of the tomato genotypes to $T$. urticae was assessed with the thumbtack bioassay, developed by Weston and Snyder (1990), measuring the distances covered by the arthropods on the adaxial leaflets surface, after 5, 10, 15, and $20 \mathrm{~min}$, recorded from the placement of five mites in the head of a metallic thumbtack, which were placed in the center of the leaflets.

In order to quantify the glandular trichomes (types I, IV, VI, and VII) (Glas et al., 2012), the same plants used for the accession of acylsugar content were also used. Five young and expanded leaflets were collected from the upper third of each plant after 30,45, 60, 75, and 90 days from sowing and, after that, the number of glandular trichome per $\mathrm{cm}^{2}$ was assessed on both adaxial and abaxial surfaces. The trichome density was assessed with an aid of a microscope stereoscope (40X), with a micrometer scale of $1 \mathrm{~cm}^{2}$.

After analyses of variance (ANOVA), normality distribution of the residuals (Kolmogorov test), homogeneity of variances (Levene test), and additivity effects between blocks and treatments were performed (F-test, $\mathrm{P}<0.05)$, in case of a significant effect $(\mathrm{P}<$ $0.05)$, the Scott-Knott test was used for the analysis of acylsugar content and the presence of trichomes, two-spotted spider mites, and silverleaf whitefly. The analyses were done by the statistical application, GENES (Cruz, 2013). Selected contrasts were done by the Scheffé test $(\mathrm{P}<0.05$ and $<0.01)$, using the statistical package SISVAR 5.3 (Ferreira, 2011), in order to compare the check treatments versus group of genotypes. Linear regression models and determination coefficients were adjusted for trichome density $(30,45,60,75$, and 90 days after sowing) and for repellence to the mites (5, 10, 15, and $20 \mathrm{~min}$ after the placement of it).

\section{RESULTS AND DISCUSSION}

A significant difference was observed between the evaluated genotypes, about the acylsugar content (Table 1). As expected, the wild accession $S$. pennellii significantly differed from the susceptible check treatments (cv. Santa Clara, UFU-73, and UFU-2). The wild species was $237.23 \%$ higher than the cv. Santa Clara (susceptible check treatment). These results corroborate with recent studies that were done with tomato plants of Santa Cruz type (Maluf et al., 2010; Maciel et al., 2011; Oliveira et al., 2012; Neiva et al., 2013). The genotypes UFU$22-\mathrm{F}_{2} \mathrm{BC}_{1} \# 9$ and UFU-73- $\mathrm{F}_{2} \mathrm{BC}_{1} \# 11$ stood out and showed significant difference from the $\mathrm{cv}$. Santa Clara and from both pre-commercial lines (UFU-2 and UFU-73), which were used as genetic backgrounds. They showed 117.07 and $227.07 \%$, respectively, of relative superiority in the acylsugar content on the leaflets $\left(\mathrm{nmol} / \mathrm{cm}^{2}\right.$ leaf area) in relation to the $\mathrm{cv}$. Santa Clara (Table 1). Gonçalves Neto et al. (2010) obtained, in tomato genotypes of Santa Cruz type, lines with high acylsugar content and satisfactory levels of resistance to the South American Tomato Pinworm (Tuta absoluta, Meyrick) (Lepidoptera: Gelechiidae) and, after that, hybrids with broad-spectrum to pests (Maluf et al., 2010; Maciel et al., 2011). Nowadays, in mini tomatoes, there are no advanced researches that aim obtaining germplasm rich in acylsugar. In this study, the genotypes UFU-22- $\mathrm{F}_{2} \mathrm{BC}_{1} \# 9$ and UFU-73- $\mathrm{F}_{2} \mathrm{BC}_{1} \# 11$ showed high acylsugar content on the leaflets, making them potential materials for genetic breeding programs, even though they were 35.63 and $32.66 \%$, respectively, lower in acylsugar content than the wild accession. Besides these results, there are reports of others showing the existence of unknown factors controlling the presence of acylsugar that could be lost during the advancement

Genetics and Molecular Research 16 (1): gmr16019539 
of the generations, being able to obtain genotypes similar to the wild species $S$. pennellii (Gonçalves et al., 2007; Gonçalves Neto et al., 2010, Maluf et al., 2010; Maciel et al., 2011). It is noteworthy to mention that the presence of acylsugar is due to an action of a recessive allele, with incomplete dominance towards low level (Gonçalves et al., 2007), which can also affect the obtaining of genotypes similar to the wild species.

On the other hand, after comparing the selected contrast " $\mathrm{C} 1$ " (wild accession versus check treatments $)$, it is evident the genetic potential of the wild accession $\left(24.0 \mathrm{nmol} / \mathrm{cm}^{2}\right.$ leaf area) (Table 1). The result ( $18.0 \mathrm{nmol} / \mathrm{cm}^{2}$ leaf area) obtained on " $\mathrm{C} 2$ " (genotypes $\mathrm{F}_{2} \mathrm{BC}_{1}$ versus S. pennellii) corroborates with the results obtained by Gonçalves et al. (2007), in relation to the possibility of another factors controlling the presence of acylsugar in S. pennellii, but these factors do not prevent the obtaining of genotypes in advanced generations, with satisfactory levels of resistance to pests (Gonçalves et al., 2007; Gonçalves Neto et al., 2010; Maluf et al., 2010; Maciel et al., 2011; Oliveira et al., 2012; Neiva et al., 2013). This can be confirmed by analyzing the "C3" (genotypes $\mathrm{F}_{2} \mathrm{BC}_{1}$ versus check treatments, $c v$. Santa Clara, UFU-73 and UFU-2), which revealed a significant increment $(\mathrm{P}<0.05$; Scheffé test) when analyzing the $\mathrm{F}_{2} \mathrm{BC}_{1}$ genotypes over the acylsugar content.

Table 1. Oviposition, number of nymphs and number of adults of Bemisia tabaci (mean number $/ \mathrm{cm}^{2}$ leaf area) in the upper third portion of tomato plants (measured 10 days after infestation) and acylsugar content $\left(\mathrm{nmol} / \mathrm{cm}^{-2}\right.$ leaf area) and relative superiority (\%) in mini tomato genotypes in the $\mathrm{F}_{2} \mathrm{BC}_{1}$ generation (Monte Carmelo, UFU, 2016).

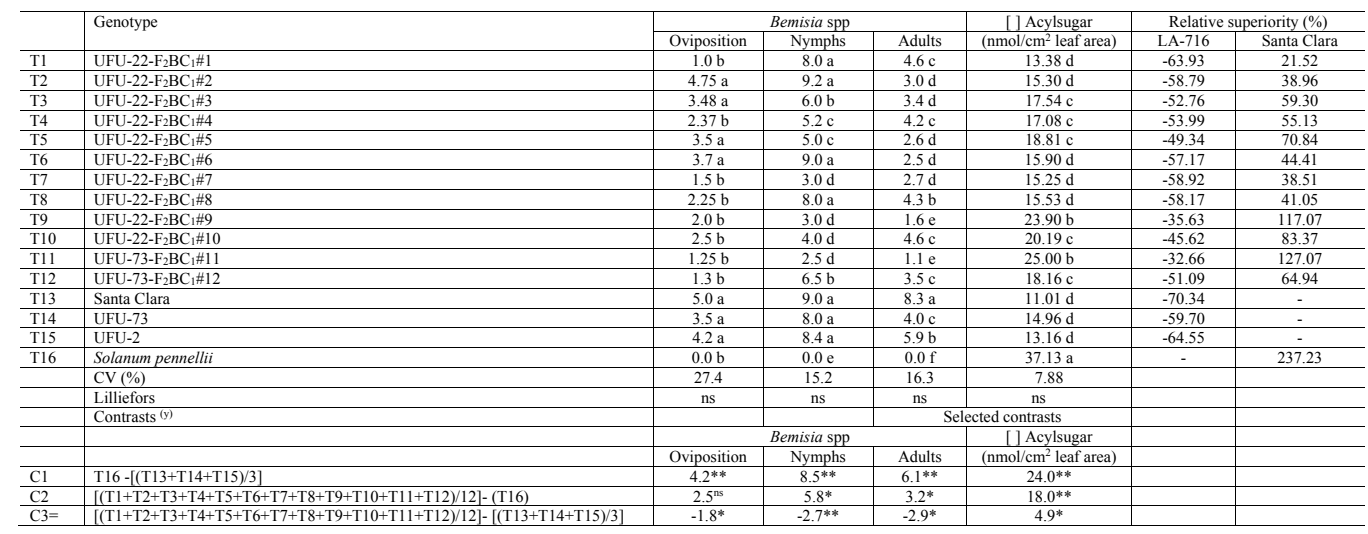

Means followed by the same letter in the column do not differ significantly from each other by the Scott-Knott test $(\mathrm{P}<0.05)$ and ${ }^{* *}, *$, and ${ }^{\mathrm{ns}}=$ significant $0.01,0.05$, and not significantly, respectively, by the Scheffé test.

There was a significant effect among the evaluated genotypes for oviposition, development of nymphs and adults (Scott-Knott, $\mathrm{P}<0.05$ ) (Table 1). During the evaluation, eggs, nymphs, and adults were not found on the wild accession S. pennellii, indicating a noninsect preference to the wild genotype. On the other hand, the cv. Santa Clara showed the highest values for the presence of eggs, nymphs, and adults (5, 9, and 8.3, respectively). Analyzing the number of eggs $/ \mathrm{cm}^{2}$, there was not insect preference for the mini tomato genotypes (UFU$22-\mathrm{F}_{2} \mathrm{BC}_{1} \# 1$, UFU-22- $\mathrm{F}_{2} \mathrm{BC}_{1} \# 4$, UFU-22- $\mathrm{F}_{2} \mathrm{BC}_{1} \# 7$, UFU-22- $\mathrm{F}_{2} \mathrm{BC}_{1} \# 8$, UFU-22- $\mathrm{F}_{2} \mathrm{BC}_{1} \# 9$, UFU-22- $\mathrm{F}_{2} \mathrm{BC}_{1} \# 10$, UFU-73- $\mathrm{F}_{2} \mathrm{BC}_{1} \# 11$, and UFU-73- $\mathrm{F}_{2} \mathrm{BC}_{1} \# 12$ ) when they were compared to the cv. Santa Clara. In relation to the number of nymphs $/ \mathrm{cm}^{2}$, the genotypes, UFU-22$\mathrm{F}_{2} \mathrm{BC}_{1} \# 9$, UFU-22- $\mathrm{F}_{2} \mathrm{BC}_{1} \# 10$, and UFU-73- $\mathrm{F}_{2} \mathrm{BC}_{1} \# 11$, highlighted showing the lowest rates 
of preference (Table 1). In tomato genotypes, there is evidence of hybrids (Santa Cruz type) with satisfactory levels of resistance to the silverleaf whitefly (Maciel et al., 2011; Maluf et al., 2010, Neiva et al., 2013). Despite the existence of mini tomato genotypes with commercial potential (Maciel et al., 2016), nowadays, there are no mini tomato genotypes rich in acylsugar with satisfactory levels of resistance to the silverleaf whitefly. It is important to emphasize that the genotypes UFU-22- $\mathrm{F}_{2} \mathrm{BC}_{1} \# 9$ and UFU-73- $\mathrm{F}_{2} \mathrm{BC}_{1} \# 11$, previously identified as rich in acylsugar (23.9 and $25.0 \mathrm{nmol} / \mathrm{cm}^{2}$ leaf area, respectively), showed no preference for the adults of whitefly during the evaluated infestation period (Table 1).

The importance of the acylsugar on the leaflets is evidenced by the selected contrasts (Table 1). Analyzing the "Cl", it is evident that the wild accession S. pennellii showed no preference for the silverleaf whitefly, in relation to the number of eggs, nymphs, and adults (4.2, 8.5, and 6.1, respectively). The mini tomato genotypes, $\mathrm{F}_{2} \mathrm{BC}_{1}$, were compared to the wild species in "C2". In fact, S. pennellii was better than the genotypes, even though it was possible to verify a non-preference, especially analyzing individually the lines per se UFU22$\mathrm{F}_{2} \mathrm{BC}_{1} \# 9$ and UFU-73- $\mathrm{F}_{2} \mathrm{BC}_{1} \# 11$ of the $\mathrm{F}_{2} \mathrm{BC}_{1}$ group. It is worth mentioning that the $\mathrm{F}_{2} \mathrm{BC}_{1}$ genotypes were better, in a general way, than the susceptible check treatment (cv. Santa Clara), for the variables: number of eggs, nymphs and adults ("C 3 " $=-1.8 ;-2.7$, and -2.9) (Table 1).

The regression equations and the determination coefficient, which were obtained from the regression analyses, made for the mite repellence test are shown in Figure 1. The distance covered by the spider mites, on the leaflets of the wild accession, S. pennellii, during the evaluation time (5, $10,15$, and $20 \mathrm{~min})$, was shorter $(<0.2 \mathrm{~cm})$ than in all other treatments, indicating repellence. These results corroborate with many studies that evaluated the mite repellence on tomato genotypes of Santa Cruz type (Pereira et al., 2008; Maluf et al., 2007, 2010). On the other hand, the higher distances covered were obtained on the check treatments, cv. Santa Clara, UFU-2, and UFU-73. Many authors have studied the mite behavior and have done associations between the acylsugar content and the repellence to the two-spotted spider mites. The possibility of obtaining tomato lines and hybrids of Santa Cruz type rich in acylsugar on the leaflets and resistant to the mite has already been verified (Pereira et al., 2008; Maluf et al., 2007, 2010). In this study, the mini tomato genotypes, UFU-22- $\mathrm{F}_{2} \mathrm{BC}_{1} \# 4$, UFU-22- $\mathrm{F}_{2} \mathrm{BC}_{1} \# 5$, UFU-22- $\mathrm{F}_{2} \mathrm{BC}_{1} \# 6$, UFU-22- $\mathrm{F}_{2} \mathrm{BC} \mathrm{C}_{1} \# 7$, UFU-22- $\mathrm{F}_{2} \mathrm{BC}_{1} \# 9$, UFU-22- $\mathrm{F}_{2} \mathrm{BC}_{1} \# 10$, UFU-73- $\mathrm{F}_{2} \mathrm{BC}_{1} \# 11$, and UFU-73- $\mathrm{F}_{2} \mathrm{BC}_{1} \# 12$ stood out for having lower distance covered by the mites on the leaflets (Figure 1). It is worth mentioning that the genotypes UFU-22- $\mathrm{F}_{2} \mathrm{BC}_{1} \# 9$ and UFU-73- $\mathrm{F}_{2} \mathrm{BC}_{1} \# 11$, previously evaluated, showed high acylsugar content (Table 1) and repellence to the two-spotted spider mites (Figure 1).

The regression equations and the determination coefficient, which were obtained from the regression analyses, made for the number of trichomes $/ \mathrm{cm}^{2}$ leaf area are shown in Figure 2. The wild accession, S. pennellii, showed higher number of glandular trichomes (types I, IV, VI, and VII) (Glas et al., 2012) than the other treatments that were evaluated. On the other hand, the $c v$. Santa Clara had the lowest number of glandular trichomes. Higher amounts of acylsugar exudates by leaflets might be associated with the presence of trichomes (Gonçalves et al., 2007) and, consequently, may proportionate resistance to pests in tomato plants (Maluf et al., 2007). The genotypes UFU-22- $\mathrm{F}_{2} \mathrm{BC}_{1} \# 9$ and UFU-73- $\mathrm{F}_{2} \mathrm{BC}_{1} \# 11$, rich in acylsugar, showed higher presence of trichomes, on the abaxial and adaxial parts, than the check treatments ( $c v$. Santa Clara, UFU-73, and UFU-2). Moreover, it is noteworthy that the number of trichomes decreased when the evaluations were made $(30,45,60,75$, and 90 days after sowing), more sharply in the check treatments, approaching zero. Analyzing the frequency of trichomes, on the leaflets of the wild accession S. pennellii, it was possible to verify that it kept high

Genetics and Molecular Research 16 (1): gmr16019539 
throughout the study. Among the $\mathrm{F}_{2} \mathrm{BC}_{1}$ genotypes, only the material UFU-73- $\mathrm{F}_{2} \mathrm{BC}_{1} \# 11 \mathrm{kept}$, until the last evaluation (90 days after sowing), a high amount of trichomes, especially when compared to the check treatments ( $c v$. Santa Clara, UFU-73, and UFU-2).

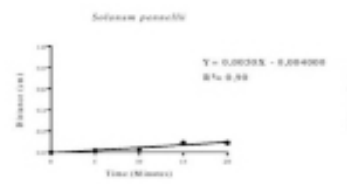

m.nacin

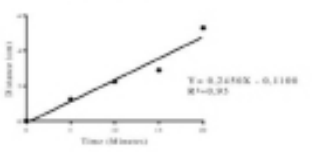

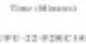

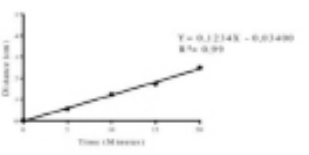

vou naser

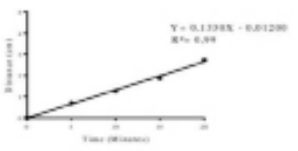

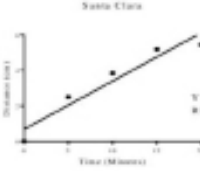

unemenest

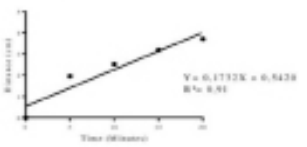

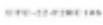

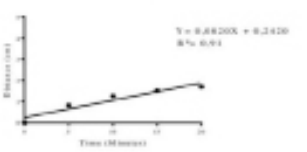

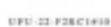

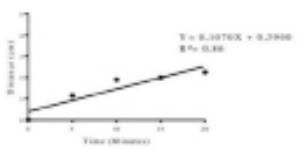

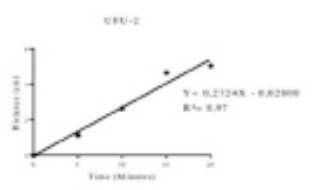

upe:masem

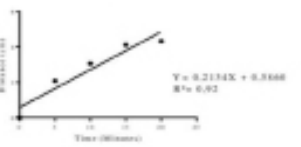

ene:meancien

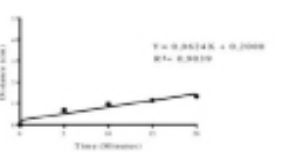

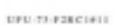

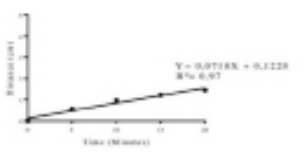

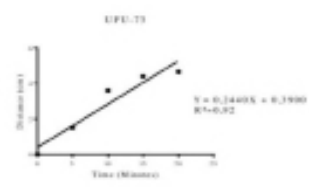

in-merto

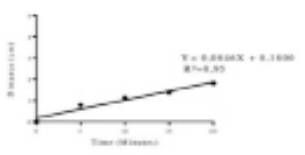

netmenton

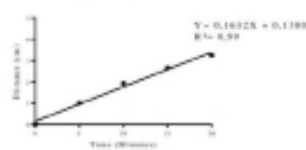

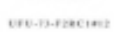

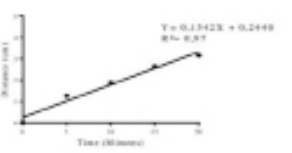

Figure 1. Regression equations for the average distance, covered by Tetranychus urticae, in function of the time (5, 10, 15, and $20 \mathrm{~min}$ ) at different tomato genotypes (Monte Carmelo, UFU, 2016).
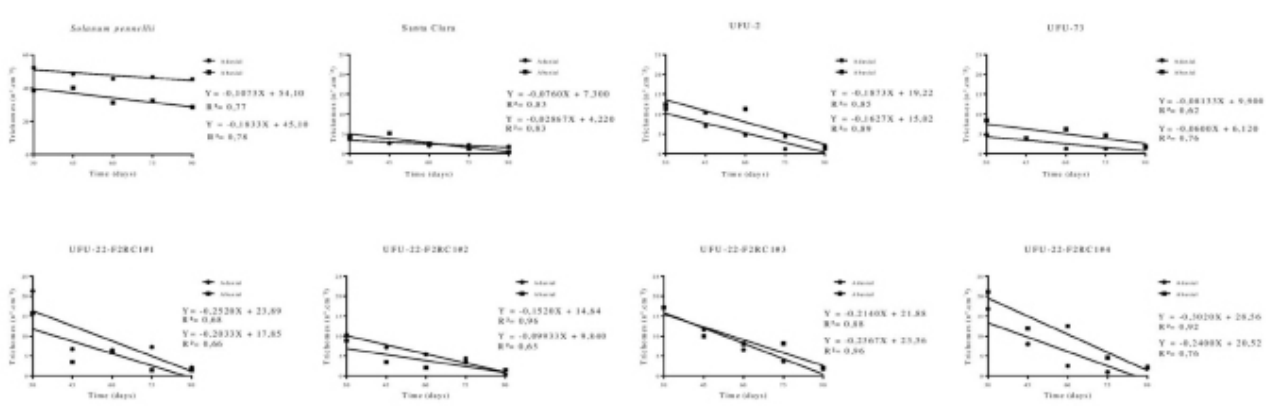

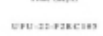
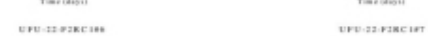

(1)
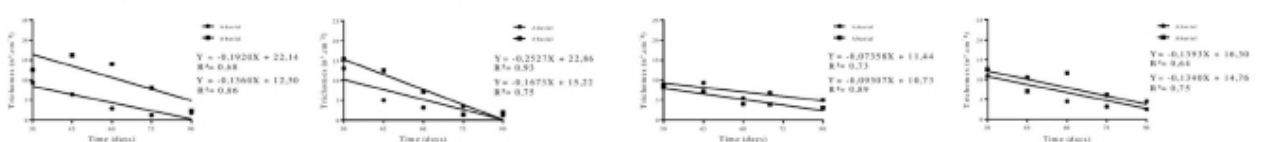

umponacies

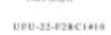
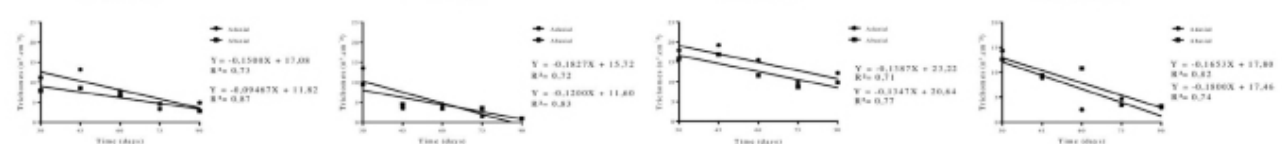

Figure 2. Regression equations for the trichome average, on the abaxial and adaxial face, of tomato leaflets at 30 , 45, 60, 75, and 90 days after sowing (Monte Carmelo, UFU, 2016).

Genetics and Molecular Research 16 (1): gmr16019539 
The genotypes UFU-22- $\mathrm{F}_{2} \mathrm{BC} \# 9$ and UFU-73- $\mathrm{F}_{2} \mathrm{BC}_{1} \# 11$ are rich in the allelochemical acylsugar and have resistance to the silverleaf whitefly and to the two-spotted spider mites.

New studies must be realized in order to obtain homozygote lines and commercial hybrids of mini tomatoes, with broad-spectrum resistance to pests.

\section{Conflicts of interest}

The authors declare no conflict of interest.

\section{ACKNOWLEDGMENTS}

The authors would like to thank Universidade Federal de Uberlândia, CNPq, and FAPEMIG for the financial support on this research project.

\section{REFERENCES}

ABCSEM - Associação Brasileira de Comércio de Sementes e Mudas (2014). Dados do setor de pesquisa de mercado de sementes de hortaliças. ABCSEM, Campinas.

Alvarenga MAR, Melo PCT and Shirahige FH (2013). Tomate - Produção em campo, casa de vegetação e hidroponia. 2nd edn. UFLA, Lavras.

Cruz CD (2013). GENES: A software package for analysis in experimental statistics and quantitative genetics. Acta Sci. Agron. (Online) 35: 271-276.

Czepak C, Albernaz KC, Vivan LM, Guimarães HO, et al. (2013). Primeiro registro de ocorrência de Helicoverpa armigera (Hübner) (Lepidoptera: Noctuidae) no Brasil. Pesqui. Agropecu. Trop. 43: 110-113. http://dx.doi.org/10.1590/S1983$\underline{40632013000100015}$

Dinsdale A, Cook L, Riginos C, Buckley YM, et al. (2010). Refined global analysis of Bemisia tabaci (Hemiptera: Sternorrhyncha: Aleyrodoidea: Aleyrodidae) mitochondrial cytochrome oxidase 1 to identify species level genetic boundaries. Ann. Entomol. Soc. Am. 103: 196-208. http://dx.doi.org/10.1603/AN09061

Esashika DAS, Michereff-filho M, Bastos CS, Inoue-Nagata AK, et al. (2016). Suscetibilidade de adultos de Bemisia tabaci, biótipo B, a inseticidas. Hortic. Bras. 34: 189-195. http://dx.doi.org/10.1590/S0102-053620160000200007

Ferreira DF (2011). Sisvar: a computer statistical analysis system. Cienc. Agrotec. 35: 1039-1042.

Glas JJ, Schimmel BCJ, Alba JM, Escobar-Bravo R, et al. (2012). Plant glandular trichomes as targets for breeding or engineering of resistance to herbivores. Int. J. Mol. Sci. 13: 17077-17103. http://dx.doi.org/10.3390/ijms131217077

Gonçalves LD, Maluf WR, Cardoso MG, Gomes LAA, et al. (2007). Herança de acilaçúcares em genótipos de tomateiro provenientes de cruzamento interespecífico. Pesqui. Agropecu. Bras. 42: 699-705. http://dx.doi.org/10.1590/S0100204X2007000500013

Gonçalves Neto AC, Silva VF, Maluf WR, Maciel GM, et al. (2010). Resistência à traça-do-tomateiro em plantas com altos teores de acilaçúcares nas folhas. Hortic. Bras. 28: 203-208. http://dx.doi.org/10.1590/S0102-05362010000200011

Maciel GM and Silva EC (2014). Proposta metodológica para quantificação de acilaçúcares em folíolos de tomateiro. Hortic. Bras. 32: 174-177. http://dx.doi.org/10.1590/S0102-05362014000200009

Maciel GM, Maluf WR, Silva VF, Gonçalves Neto AC, et al. (2009). Heterose e capacidade combinatória em linhagens de tomateiro na obtenção de híbridos com teores intermediários de acilaçúcares. Hortic. Bras. 27: 1161-1167.

Maciel GM, Maluf WR, Silva VF, Gonçalves Neto AC, et al. (2011). Híbridos pré-comerciais resistentes a Tuta absoluta obtidos de linhagem de tomateiro rica em acilaçúcares. Hortic. Bras. 29: 151-156. http://dx.doi.org/10.1590/S0102$\underline{05362011000200003}$

Maciel GM, Fernandes MAR, Melo OD and Oliveira CS (2016). Potencial agronômico de híbridos de minitomate com hábito de crescimento determinado e indeterminado. Hortic. Bras. 34: 144-148. http://dx.doi.org/10.1590/S0102$\underline{053620160000100022}$

Maluf WR, Inoue IF, Ferreira RPD, Gomes LAA, et al. (2007). Higher glandular trichome density in tomato leaflets and repellence to spider mites. Pesqui. Agropecu. Bras. 42: 1227-1235. http://dx.doi.org/10.1590/S0100-204X2007000900003

Maluf WR, Maciel GM, Gomes LAA, Cardoso MG, et al. (2010). Broad-spectrum arthropod resistance in hybrids between high and low-acylsugar tomato lines. Crop Sci. 50: 439-450. http://dx.doi.org/10.2135/cropsci2009.01.0045

Genetics and Molecular Research 16 (1): gmr16019539 
Neiva IP, Andrade Júnior VC, Maluf WR, Oliveira CM, et al. (2013). Role of allelochemicals and trichome density in the resistance of tomato to whitefly. Cienc. Agrotec. 37: 61-67. http://dx.doi.org/10.1590/S1413-70542013000100007

Oliveira CM, Andrade Júnior VC, Maluf WR, Neiva IP, et al. (2012). Resistance of tomato strains to the moth Tuta absoluta imparted by allelochemicals and trichome density. Cienc. Agrotec. 36: 45-52.

Pereira GVN, Maluf WR, Gonçalves LD, Nascimento IR, et al. (2008). Seleção para alto teor de acilaçúcares em genótipos de tomateiro e sua relação com a resistência ao ácaro vermelho (Tetranychus evansi) e à traça (Tuta absoluta). Cienc. Agrotec. 32: 996-1004. http://dx.doi.org/10.1590/S1413-70542008000300045

Resende JTV, Cardoso MG, Maluf WR, Santos CD, et al. (2002). Método colorimétrico para quantificação de acilaçúcar em genótipos de tomateiro. Cienc. Agrotec. 26: 1204-1208.

Sato ME (2015). Ácaro rajado em tomate tem assustado produtores. Campo \& Negócios. 8: 26-28.

Sato ME, Silva MZ, Silva RB, Souza Filho MF, et al. (2009). Monitoramento da resistência de Tetranychus urticae Koch (Acari: Tetranychidae) a Abamectin e Fenpyroximate em diversas culturas no estado de São Paulo. Arq. Inst. Biol. (Sao Paulo) 76: 217-223.

Silveira LFV, Polanczyk D and Pratissoli CR (2011). Franco Seleção de isolados de Bacillus thuringiensis Berliner para Tetranychus urticae Koch. Arq. Inst. Biol. (Sao Paulo) 78: 273-278.

Weston PA and Snyder JC (1990). Thumbtack biossay: a quick method of measuring plant resistence to two-spotted spider mites (Acari: Tetranychidae). J. Econ. Entomol. 83: 501-504. http://dx.doi.org/10.1093/jee/83.2.500

Genetics and Molecular Research 16 (1): gmr16019539 